\title{
Geochemical weathering of aeolian sand and its palaeoclimatic implications in the Mu Us Desert, northern China, since the Late Holocene
}

\author{
LIU Bing ${ }^{1,2,3}$, JIN Heling ${ }^{1,2^{*}}$, SUN Zhong ${ }^{2}$, ZHAO Shuang ${ }^{3}$ \\ ${ }^{1}$ State Key Laboratory of Earth Surface Processes and Resource Ecology, Beijing Normal University, Beijing 100875, China; \\ ${ }^{2}$ Key Laboratory of Desert and Desertification, Cold and Arid Regions Environmental and Engineering Research Institute, \\ Chinese Academy of Sciences, Lanzhou 730000, China; \\ ${ }^{3}$ Key Laboratory of Western China's Environmental System (Ministry of Education), Lanzhou University, Lanzhou 730000, \\ China
}

\begin{abstract}
In the semi-arid and arid regions of northern China, geochemical behavior of the aeolian deposit is closely related to climatic and environmental changes, which was used to reconstruct the past history of environmental evolution and possibly forcing mechanisms. However, the related result was still scarce due to the lack of detailed geochemical analysis results in the desert sediments. In the present study, we systematically analyzed the geochemical components and parameters of the paleo-aeolian sand dune and modern mobile sand deposits in the Mu Us Desert and discuss the climatic variation inferred from the paleo-aeolian sand dune during the past $4.2 \mathrm{ka}$ $\mathrm{BP}$. The results indicated that (1) geochemical composition of the sandy deposits were dominated by $\mathrm{SiO}_{2}, \mathrm{Al}_{2} \mathrm{O}_{3}$ and $\mathrm{Na}_{2} \mathrm{O}$ and the deposits probably originated from the widespread upper continental crust (UCC) and were formed by long-term weathering, transport and re-deposition; (2) these sandy deposits were subjected to weaker weathering or uneven weathering under cold and dry conditions, and had highly similar material sources and degrees of weathering and leaching in general; and (3) the direct OSL (Optically Stimulated Luminescence) dating ages and geochemical parameters from the palaeosol-aeolian sand dune indicated that the regional climate change experienced several typically cold and warm intervals. These intervals are 4.2, $2.8 \mathrm{ka} \mathrm{BP}$ and Little Ice Age and Medieval Warm Period, which probably attributed to periodic variations of the Asian summer monsoonal strength and cold events of the northern Atlantic Ocean in low and high latitudes of the Northern Hemisphere. Our results suggest that the development of the sand dune in the Mu Us Desert provided a suitable archive for understanding the past local climatic change, which is linked to the global climatic change.
\end{abstract}

Keywords: climatic change; geochemical component; weathering degree; Late Holocene; Mu Us Desert

Citation: LIU Bing, JIN Heling, SUN Zhong, ZHAO Shuang. 2016. Geochemical weathering of aeolian sand and its palaeoclimatic implications in the Mu Us Desert, northern China, since the Late Holocene. Journal of Arid Land, 8(5): 647-659. doi: 10.1007/s40333-016-0014-y

Chemical weathering is not only the main form of interaction with the different spheres on the surface layer of the Earth, but is also an important link of the element circulation in the supergene geochemical process (Nesbitt and Young, 1982; Fedo et al., 1995; Chen et al., 1998, 2001). Chemical behaviors of aeolian deposits during the weathering process can reveal the geochemical components of the deposits and their weathering degree. By comparing the geochemical

*Corresponding author: JIN Heling (E-mail: jinhl@lzb.ac.cn)
Received 2015-12-22; revised 2016-04-19; accepted 2016-04-25
(C) Xinjiang Institute of Ecology and Geography, Chinese Academy of Sciences, Science Press and Springer-Verlag Berlin Heidelberg 2016 
components of the deposits in the potential source and accumulation areas, we can ascertain the provenance of the aeolian materials, the transport process and the main influence factors (Guo et al., 2002; Liang et al., 2009; Qiao et al., 2009; Yao et al., 2010). The formation and evolution of sediments have a close relationship with the geological time-scale; therefore, geochemical studies can provide the technology necessary for reconstructing the past climatic and environmental history and possibly determining the forcing mechanisms.

Aeolian deposits, mainly aeolian sand, are widely distributed in the semi-arid and arid deserts in northern China. They can be regarded as indispensable geological archives for indicating palaeoclimatic and palaeoenvironmental changes because the occurrence and disappearance of these deposits are strongly controlled by the deteriorative and ameliorative regional environmental conditions and related changes in the atmospheric circulations ( $\mathrm{Lu}$ et al., 2005; Sun et al., 2006; Liu et al., 2014a). Recent geochemical researches of these deposits have mainly concentrated on the loess and Qinghai-Tibet plateaus (Chen et al., 2001, 2008; Qiao et al., 2009), the red clay in southeastern margin of China (Li et al., 1999, 2008) and the surface sandy materials in the deserts of northern China (Xu et al., 2011; Xie et al., 2013). However, studies on the Holocene aeolian sand deposits in the sandy-land or deserts near the monsoonal boundary zone in northern China for climatic inferences are limited.

In the $\mathrm{Mu}$ Us Desert, northern China, climatic change studies were carried out during the last ten years based on the OSL (Optically Stimulated Luminescence) ages and multi-proxies from the aeolian deposits, especially the palaeosol-aeolian sand sequence. Sun et al. (2006) concluded that mobile sand dunes dominated the region, and the climate became warm and humid around 9.0-5.6 ka BP, afterwards, the region again became arid with the mobile sand dunes. Ma et al. (2011) suggested that it was an arid environment before $7.5 \mathrm{ka} \mathrm{BP}$, an optimal humid interval around 7.5-3.9 ka BP, and a dry climate since then. Liu et al. (2014a, 2015) also evidenced this similar pattern of the regional climatic change, accompanied with the six millennial-scale dry events. Jia et al. (2015) discovered that the aeolian activities regionally occurred from 11.0 to 8.5 ka BP and typical sandy paleosol widely developed between 8.5 and $4.0 \mathrm{ka}$ BP. Since then the dunes have reactivated and active sand dunes have gradually increased in the $\mathrm{Mu}$ Us Desert. These results demonstrated that the region was dominated by a dry climate since the Late Holocene, nevertheless, detailed information of climatic change is still scarce. In this paper, we focused on the Late Holocene aeolian sand dune in the southeastern $\mathrm{Mu}$ Us Desert and other deposits, and used the geochemical method to understand the following issues: (1) the geochemical components and weathering degree of the sandy deposits; (2) the variation of the geochemical parameters and their environmental significance; and (3) the detailed climatic change process in the Mu Us Desert during the last $4.2 \mathrm{ka} \mathrm{BP}$.

\section{Materials and methods}

\subsection{Study area}

The Mu Us Desert $\left(37^{\circ} 27^{\prime}-39^{\circ} 22^{\prime} \mathrm{N}, 107^{\circ} 20^{\prime}-111^{\circ} 30^{\prime} \mathrm{E}\right)$ is located at the northwestern margin of the Asian monsoonal boundary, in which the climate is controlled by the alternating summer and winter monsoons (Fig. 1a). Its ground surface is dominated by fixed, semi-fixed and mobile sand dunes. The semi-fixed and fixed dunes consist of beam-like honeycomb dunes and several nabkha dunes (shrub-coppice dunes), and the mobile dunes are crescent dunes and chains of sand dunes (Fig. 1b). The region has a typical arid and semi-arid continental monsoonal climate, with an annual mean temperature of $6.0^{\circ} \mathrm{C}-9.0^{\circ} \mathrm{C}$ and annual precipitation of $200-400 \mathrm{~mm}$. The mean annual evaporation and aridity are 1,800-2,500 $\mathrm{mm}$ and 1.0-2.5, respectively. The modern vegetation is temperate and desert steppes, dominated by Artemisia ordosica, Caragana microphylla and xerophytic Gramineae.

\subsection{Profile description and sampling}

The Wangjiagou (WJG) profile $\left(38^{\circ} 47^{\prime} \mathrm{N}, 110^{\circ} 09^{\prime} \mathrm{E}\right)$, a typical palaeo-mobile sand dune, is situated in Shenmu county in the southeastern Mu Us Desert. The profile is dominated by typical 


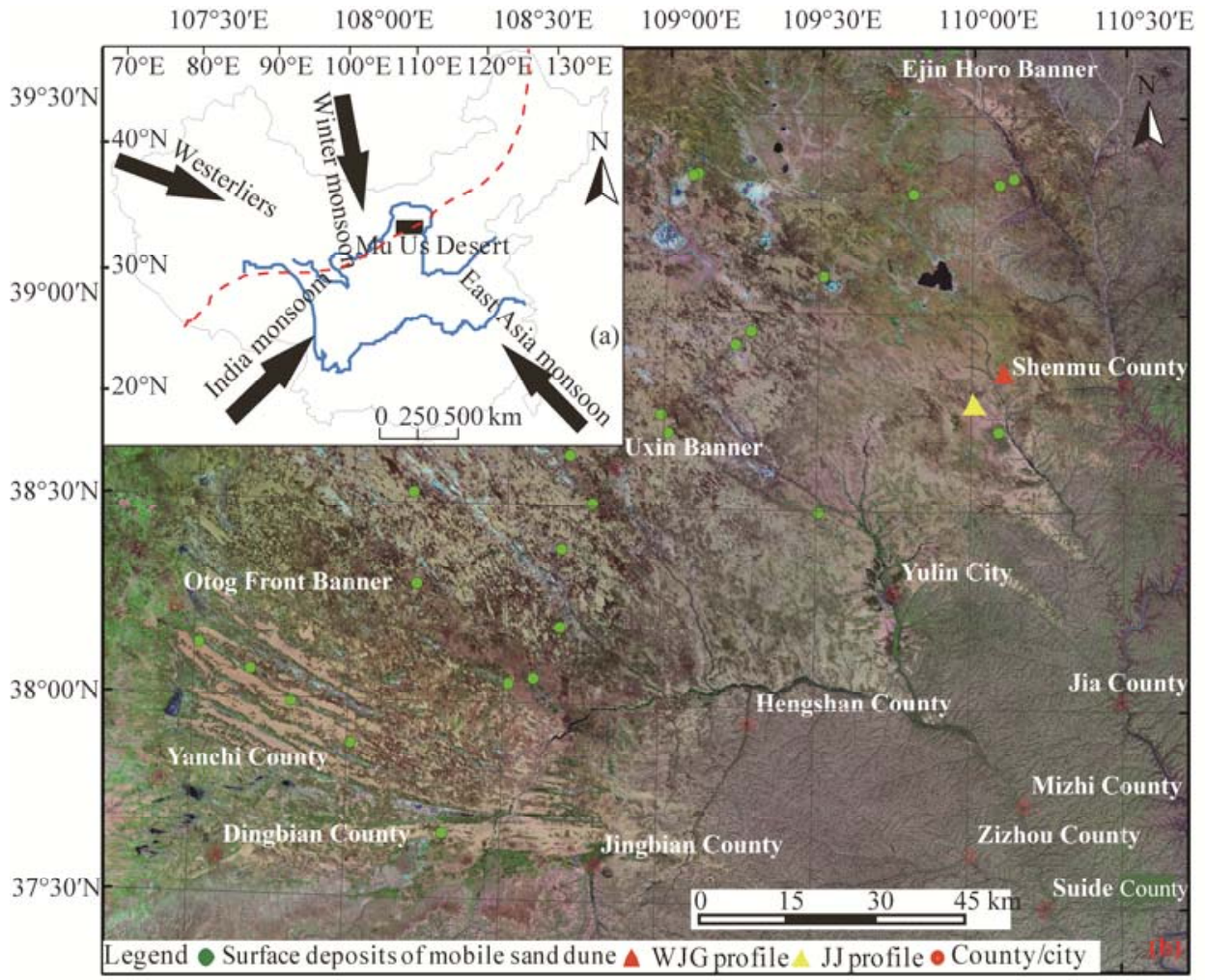

Fig. 1 Location of the study area. (a) The Mu Us Desert (black rectangle); red dashed line shows the present limit of the modern Asian summer monsoon; (b) Jinjie (JJ) profile (yellow triangle; Liu et al., 2015), Wangjiagou (WJG) profile (red triangle, this study) and surface deposits of the mobile dunes (green dots, this study).

aeolian sand in the top $306 \mathrm{~cm}$, which consists of six layers of aeolian sand deposited at different times and below it is palaeosol $(306$ to $450 \mathrm{~cm}$ ). The aeolian sand is composed of turbid yellow orange and greyish yellow medium- and fine-grained sand, moderately well-sorted, loose and with typical aeolian oblique bedding. The palaeosol is grayish yellow and light grey medium- and fine-grained sand, weakly to moderately sorted, compacted to hard and non-stratified (Fig. 2a). The OSL dating results (Fig. 2b; Table 1) indicated that the six aeolian sand layers were accumulated around 4.2, 4.2-3.0, 3.0-2.1, 2.1-1.8, 1.8-0.9 and since $0.9 \mathrm{ka} \mathrm{BP,} \mathrm{respectively.}$ These dates suggest that this paleo-aeolian sand dune was mainly formed during the Late Holocene.

A total of 151 samples were collected at $2-\mathrm{cm}$ intervals from the six sedimentary layers of the
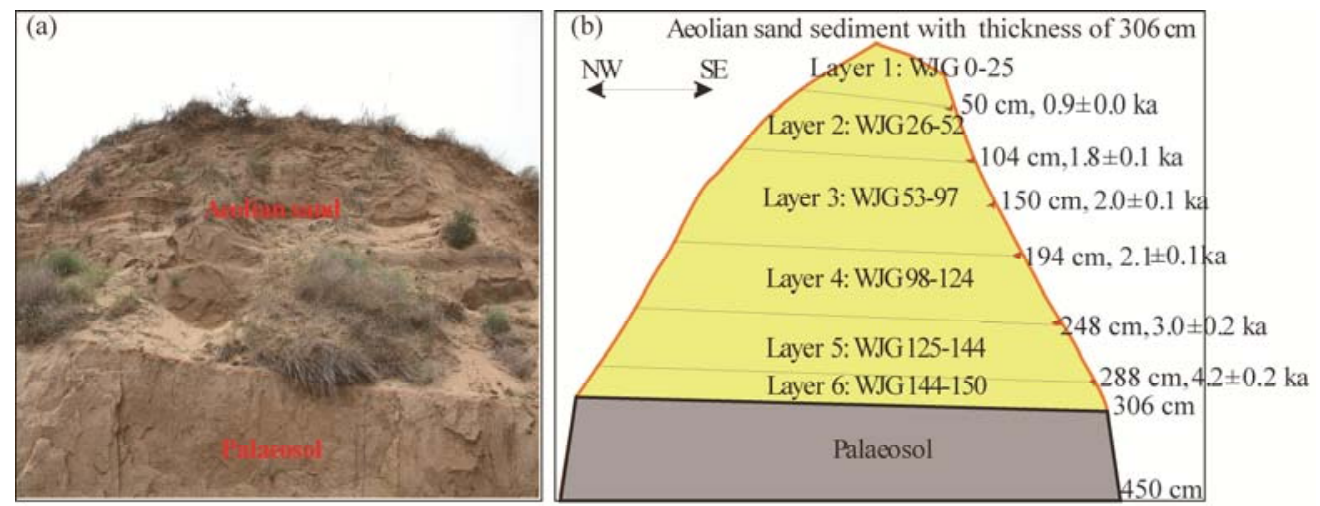

Fig. 2 Lithostratigraphic units (a) and optically stimulated luminescence ages (b) of the Wangiiagou (WJG) profile 
Table 1 Results of the OSL dating and related parameters for the Wangjiagou (WJG) profile

\begin{tabular}{lcccccccc}
\hline $\begin{array}{l}\text { No. of } \\
\text { sample }\end{array}$ & $\begin{array}{c}\text { Depth } \\
(\mathrm{cm})\end{array}$ & $\begin{array}{c}\mathrm{U} \\
\left(10^{-6}\right)\end{array}$ & $\begin{array}{c}\mathrm{Th} \\
\left(10^{-6}\right)\end{array}$ & $\begin{array}{c}\mathrm{K} \\
(\%)\end{array}$ & $\begin{array}{c}\text { Equivalent dose } \\
(\mathrm{Gy})\end{array}$ & $\begin{array}{l}\text { Dose rate } \\
(\mathrm{Gy} / \mathrm{ka})\end{array}$ & $\begin{array}{c}\text { Water content } \\
(\%)\end{array}$ & $\begin{array}{l}\text { OSL } \\
(\mathrm{ka})\end{array}$ \\
\hline WJ-25 & $45-50$ & 0.72 & 2.91 & 2.43 & $2.93 \pm 0.10$ & $3.14 \pm 0.13$ & $5 \pm 1$ & $0.9 \pm 0.0$ \\
WJ-50 & $100-105$ & 0.79 & 4.47 & 2.34 & $5.87 \pm 0.43$ & $3.22 \pm 0.13$ & $5 \pm 1$ & $1.8 \pm 0.1$ \\
WJ-75 & $150-155$ & 1.11 & 6.21 & 2.29 & $6.83 \pm 0.35$ & $3.44 \pm 0.14$ & $5 \pm 1$ & $2.0 \pm 0.1$ \\
WJ-100 & $194-199$ & 0.72 & 8.02 & 2.40 & $7.53 \pm 0.45$ & $3.58 \pm 0.14$ & $5 \pm 1$ & $2.1 \pm 0.1$ \\
WJ-125 & $250-255$ & 0.68 & 2.26 & 2.42 & $9.20 \pm 0.47$ & $3.01 \pm 0.12$ & $5 \pm 1$ & $3.0 \pm 0.2$ \\
WJ-144 & $288-293$ & 0.77 & 2.88 & 2.06 & $11.47 \pm 0.16$ & $2.74 \pm 0.11$ & $5 \pm 1$ & $4.2 \pm 0.2$ \\
\hline
\end{tabular}

Note: $U$, uranium; Th, thorium; K, potassium.

WJG profile for analysis of the geochemical elements. Meanwhile, we also collected 23 surface samples $(0-5 \mathrm{~cm})$ of modern mobile sand dunes covering the entire $\mathrm{Mu}$ Us Desert based on their spatial distributions and vegetation cover. Additionally, we also used previous data, i.e. the Holocene palaeosol (174 samples) and aeolian sand (150 samples) from the Jinjie (JJ) profile in the southeastern $\mathrm{Mu}$ Us Desert (Liu et al., 2015) for comparative analysis.

\subsection{Experiment method and geochemical parameters}

The geochemical elements were measured at the Key Laboratory of Desert and Desertification, Cold and Arid Regions Environmental and Engineering Research Institute, Chinese Academy of Sciences. The samples were dried, powdered and sieved through a 200-mesh screen. Powdered samples of $4 \mathrm{~g}$ were placed into a mold with boric acid for the edge and bottom and pressed into round slice (32 $\mathrm{mm}$ in diameter) under 30 -t pressure and $105^{\circ} \mathrm{C}$. The round slices were measured by axios-advanced $\mathrm{X}$-ray fluorescence spectrometer. The estimated error was less than $5 \%$. In this study, the major elements consisted of $\mathrm{SiO}_{2}, \mathrm{Al}_{2} \mathrm{O}_{3}, \mathrm{Fe}_{2} \mathrm{O}_{3}, \mathrm{CaO}, \mathrm{NaO}, \mathrm{K} 2 \mathrm{O}, \mathrm{MgO}, \mathrm{TiO}_{2}$ and $\mathrm{P}_{2} \mathrm{O}_{5}$, the geochemical parameters (ratios) were calculated by the aforementioned results of the contents of geochemical elements, which are composed of $\mathrm{SiO}_{2} / \mathrm{Al}_{2} \mathrm{O}_{3}$ (molecular mole), $\left(\mathrm{Al}_{2} \mathrm{O}_{3}+\mathrm{Fe}_{2} \mathrm{O}_{3}\right) /\left(\mathrm{K}_{2} \mathrm{O}+\mathrm{Na}_{2} \mathrm{O}+\mathrm{CaO}+\mathrm{MgO}\right),\left(\mathrm{K}_{2} \mathrm{O}+\mathrm{Na}_{2} \mathrm{O}+\mathrm{CaO}\right) / \mathrm{Al}_{2} \mathrm{O}_{3}, \mathrm{Na} / \mathrm{K}$ (molecular mole) and Chemical Index of Alteration (CIA).

In the study of palaeoclimatic and palaeoenvironmental changes, $\mathrm{SiO}_{2} / \mathrm{Al}_{2} \mathrm{O}_{3}$ was usually used as the index for the winter monsoonal strength and related cold-dry condition (Peng and Guo, 2001). $\left(\mathrm{Al}_{2} \mathrm{O}_{3}+\mathrm{Fe}_{2} \mathrm{O}_{3}\right) /\left(\mathrm{K}_{2} \mathrm{O}+\mathrm{Na}_{2} \mathrm{O}+\mathrm{CaO}+\mathrm{MgO}\right)$ mainly reflected the relative change of the stable $\mathrm{Al}$ and $\mathrm{Fe}$ contents and the active $\mathrm{K}, \mathrm{Na}, \mathrm{Ca}$, and $\mathrm{Mg}$ contents in the deposits, which also indirectly indicated the leaching degree of the deposits in the weathering process (Jin et al., 2003). $\left(\mathrm{K}_{2} \mathrm{O}+\mathrm{Na}_{2} \mathrm{O}+\mathrm{CaO}\right) / \mathrm{Al}_{2} \mathrm{O}_{3}$ is usually used to reflect the leaching state of alkali metal and alkaline earth in the deposits (Liu et al., 2015). $\mathrm{Na} / \mathrm{K}$ ratio is an important index for assessing the weathering degree of the plagioclase in the deposits (Taylor and McLennan, 1985). $\mathrm{CIA}=\left[\mathrm{Al}_{2} \mathrm{O}_{3} /\left(\mathrm{Al}_{2} \mathrm{O}_{3}+\mathrm{CaO}^{*}+\mathrm{K}_{2} \mathrm{O}+\mathrm{Na}_{2} \mathrm{O}\right)\right] \times 100$, where the chemical oxide values are molecular formulae and the $\mathrm{CaO}^{*}$ is the amount of $\mathrm{CaO}$ incorporated in the silicate fraction (Nesbitt and Young, 1982). The samples were not treated with acid in this study, we therefore calculated the $\mathrm{CaO}^{*}$ amount in the silicate according to the method of McLennan (1993). An increased CIA accompanies warm and humid surroundings, whereas it becomes lower when the climate tends to be cold and dry (Liu et al., 2014a). CIA of the un-weathered deposits is less than 50, the CIA of 50-65 indicates weaker geochemical weathering under cold and dry conditions, and the CIA of 65-85 reflects moderate weathering in warm and humid conditions. When the CIA is more than 85 , the geochemical weathering became stronger due to a hot and wet environment (Chen et al., 2008).

\section{Results}

\subsection{Geochemical elements}

Geochemical composition of the major elements from the WJG, JJ profiles and surface deposits 
of the modern mobile sand dune was shown in Table 2. The results demonstrated that geochemical components of these deposits were dominated by $\mathrm{SiO}_{2}, \mathrm{Al}_{2} \mathrm{O}_{3}$ and $\mathrm{Na}_{2} \mathrm{O}$. For example, the average $\mathrm{SiO}_{2}$ contents were $76.44 \%$ in the WJG profile, $78.74 \%$ in the surface deposits of the modern sand dune, and $78.99 \%$ and $77.41 \%$ in the Holocene aeolian sand and palaeosol ( $\mathrm{JJ}$ profile), respectively. The $\mathrm{Al}_{2} \mathrm{O}_{3}$ contents were $11.82 \%, 9.60 \%, 11.53 \%$ and $11.68 \%$ in the aforementioned deposits, although the $\mathrm{Al}_{2} \mathrm{O}_{3}$ content of surface deposits was relatively lower compared to other deposits. The $\mathrm{Na}_{2} \mathrm{O}$ contents were $3.90 \%$ in the WJG profile, $3.16 \%$ in the surface deposits, $3.51 \%$ and $3.35 \%$ in the Holocene aeolian sand and palaeosol, respectively. In comparison, $\mathrm{K}_{2} \mathrm{O}, \mathrm{CaO}$ and $\mathrm{Fe}_{2} \mathrm{O}_{3}$ contents were secondary and contents of the other elements $\left(\mathrm{MgO}, \mathrm{TiO}_{2}\right.$ and $\left.\mathrm{P}_{2} \mathrm{O}_{5}\right)$ were all less than $0.5 \%$ in these deposits. Further, we found that the geochemical components of the different aeolian sand layers in the WJG profile had apparent similarity, the order of their contents were $\mathrm{SiO}_{2}, \mathrm{Al}_{2} \mathrm{O}_{3}, \mathrm{Na}_{2} \mathrm{O}, \mathrm{K} 2 \mathrm{O}, \mathrm{CaO}, \mathrm{Fe}_{2} \mathrm{O}_{3}$, $\mathrm{MgO}, \mathrm{TiO}_{2}$ and $\mathrm{P}_{2} \mathrm{O}_{5}$, and the detailed data are presented in Table 2.

Figure 3 presents the UCC (upper continental crust)-normalized curves of the average chemical composition of the different types of sand materials in the $\mathrm{Mu}$ Us Desert. The results demonstrated that distribution patterns of UCC-normalized curves of the different types of the sandy deposits were very similar, which suggested that these desert sediments possibly had similar material sources and processes of transport and deposition. Compared to the UCC, the $\mathrm{SiO}_{2}$ and $\mathrm{Na}_{2} \mathrm{O}$ in the different types of sandy deposits in the $\mathrm{Mu}$ Us Desert were similar with the average chemical content of the UCC (Fig. 3). In contrast, the other elements showed clear leaching and migration that were different from the UCC. Further, we calculated the leaching and migration rate in the aforementioned elements according to the UCC-normalized values, and the orders of the element contents were as follows (from high to low): $\mathrm{Mg}>\mathrm{Fe}>\mathrm{Ca}>\mathrm{P}>\mathrm{Ti}>\mathrm{Al}>\mathrm{K}>\mathrm{Na}>\mathrm{Si}$. In general, the sandy materials in the $\mathrm{Mu}$ Us Desert were sufficiently mixed by long-term weathering, transport deposition and the partial element contents were close to the average geochemical components of the UCC, while the other elements were leaching during the geochemical weathering process.

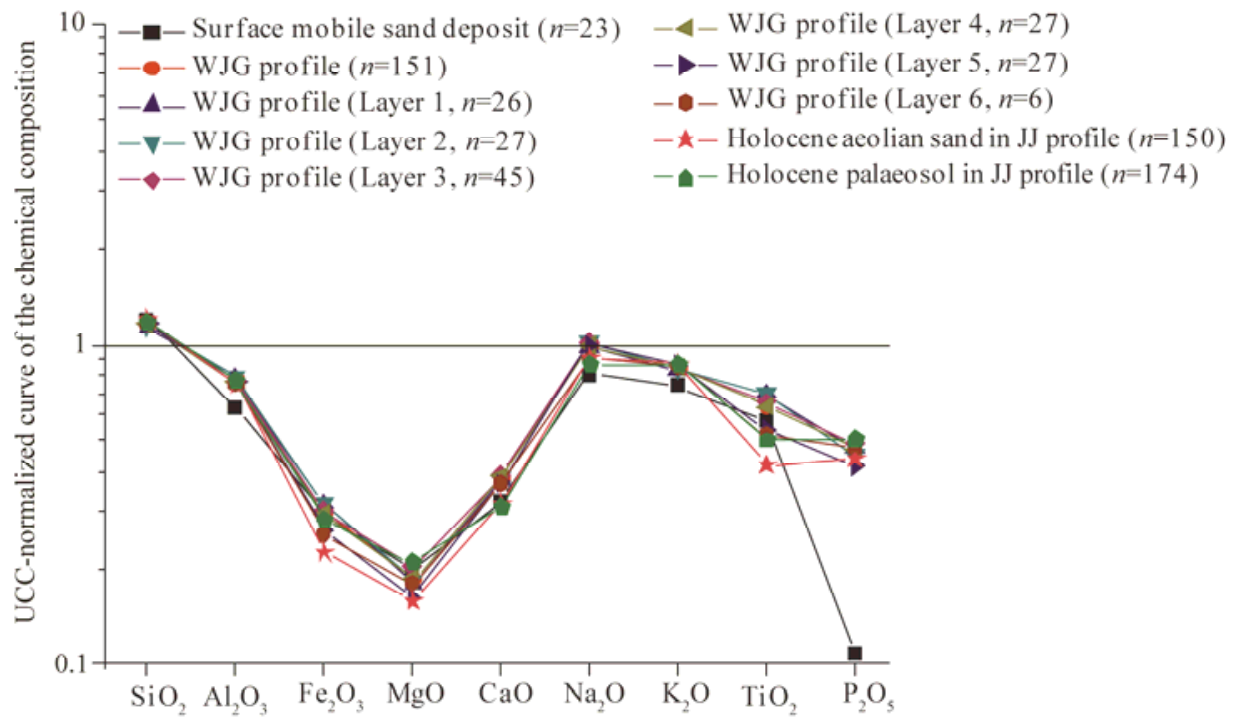

Fig. 3 UCC (upper continental crust)-normalized curves of the average contents of the geochemical elements from different deposits in the Mu Us Desert

\subsection{Geochemical parameters}

The range of $\mathrm{SiO}_{2} / \mathrm{Al}_{2} \mathrm{O}_{3}$ was $10.08-14.65$ in the WJG profile, with an average of 11.04 (Table 3). This value was roughly similar to that of the surface sandy deposits in the Mu Us Desert, whereas it was significantly higher than in the UCC, PAAS (Post-Archean Australian Shale), and Holocene aeolian deposits from the JJ profile. For the different sedimentary layers (layers 1-6) 


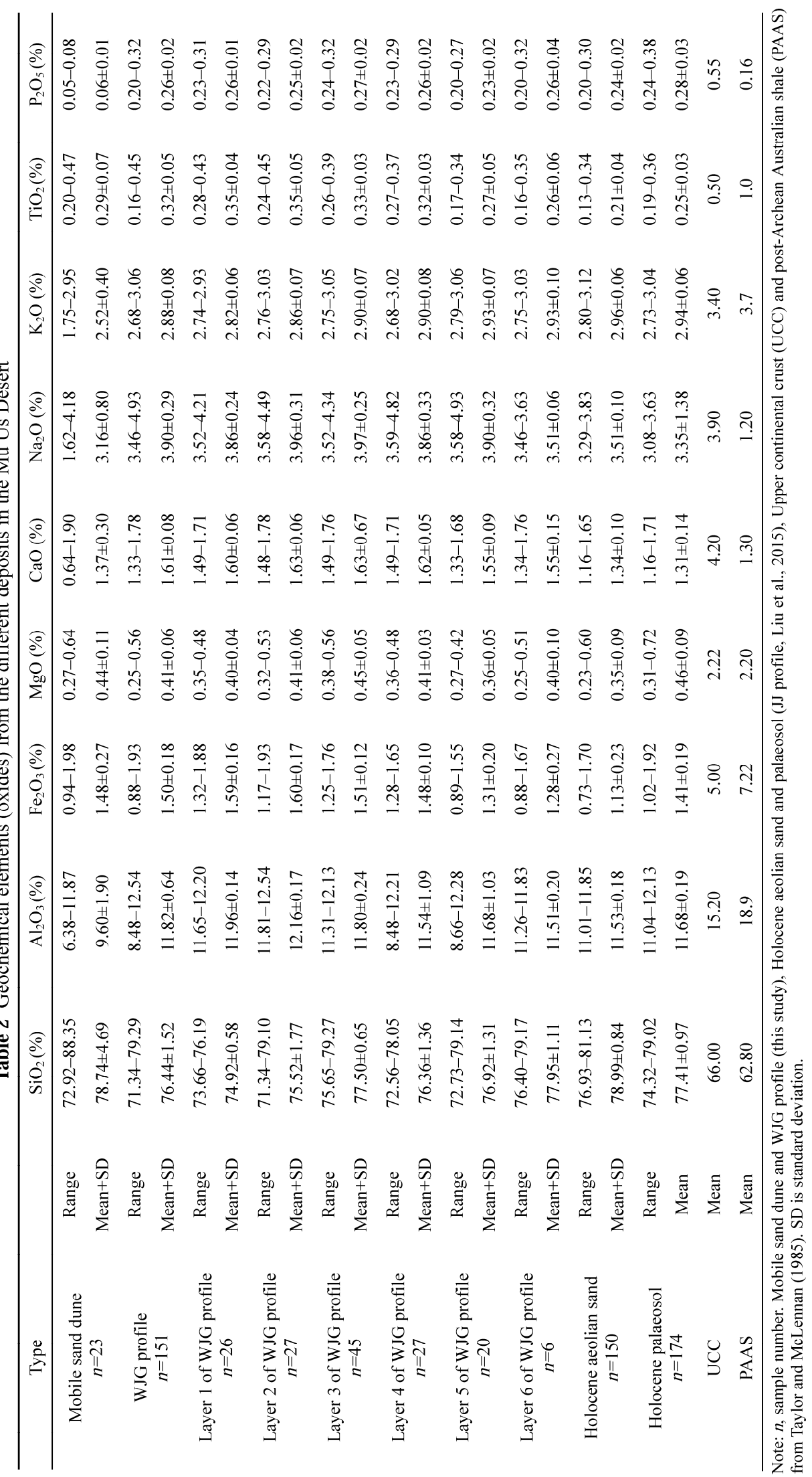




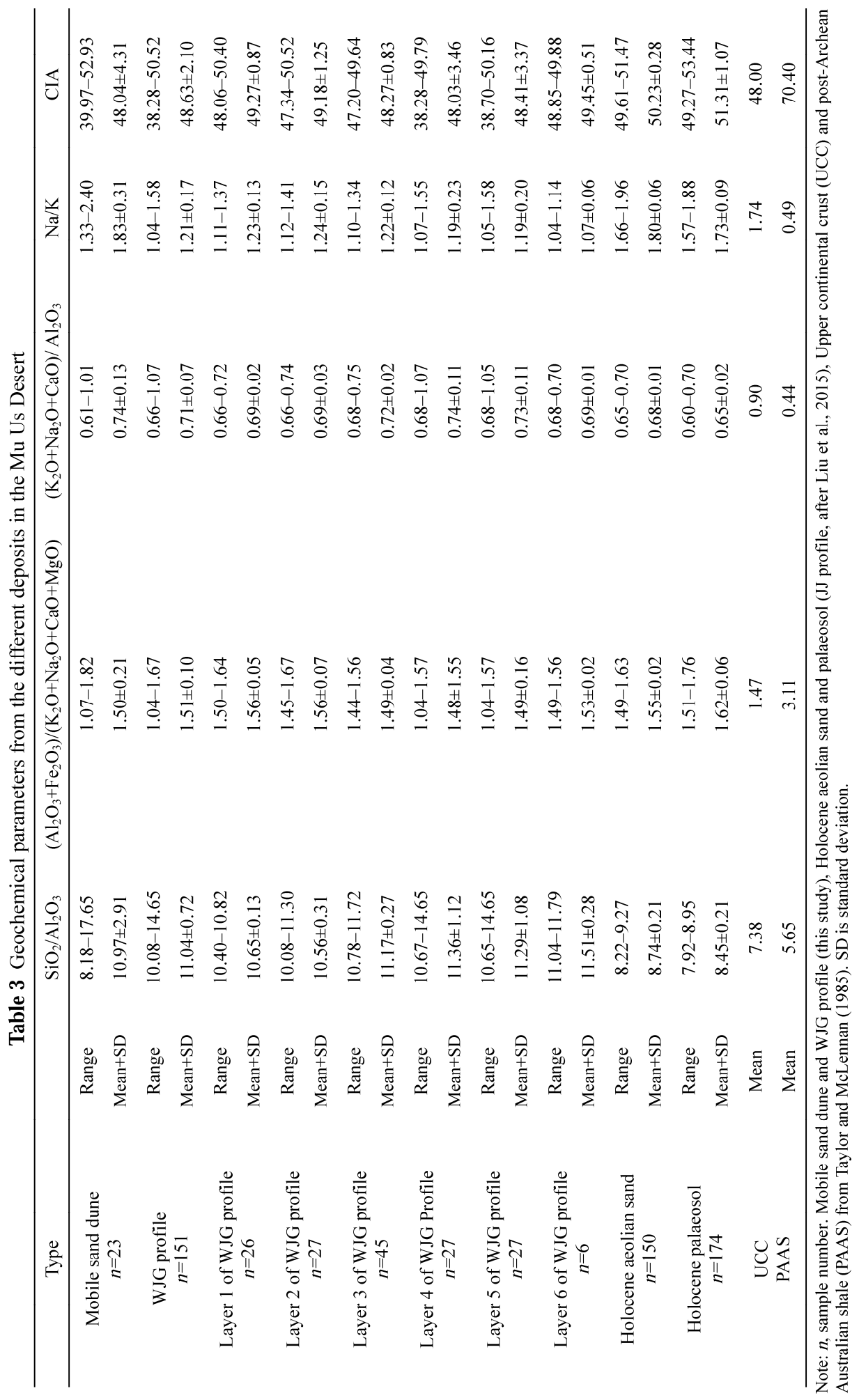


of the WJG profile, the $\mathrm{SiO}_{2} / \mathrm{Al}_{2} \mathrm{O}_{3}$ ratio showed apparent consistency (Table 3). In general, the results demonstrated relative stable environmental conditions occurred in the modern and past 4.2 ka BP, which evidenced by the similar winter monsoonal strength and cold-dry degree inferred from the $\mathrm{SiO}_{2} / \mathrm{Al}_{2} \mathrm{O}_{3}$ of the different types of sandy deposits. Additional, the relatively concentrated distributions of CIA and $\mathrm{SiO}_{2} / \mathrm{Al}_{2} \mathrm{O}_{3}$ shown in the scatter diagram in Fig. $4 \mathrm{a}$ also confirmed the analogous weathering degree and sediment maturity.

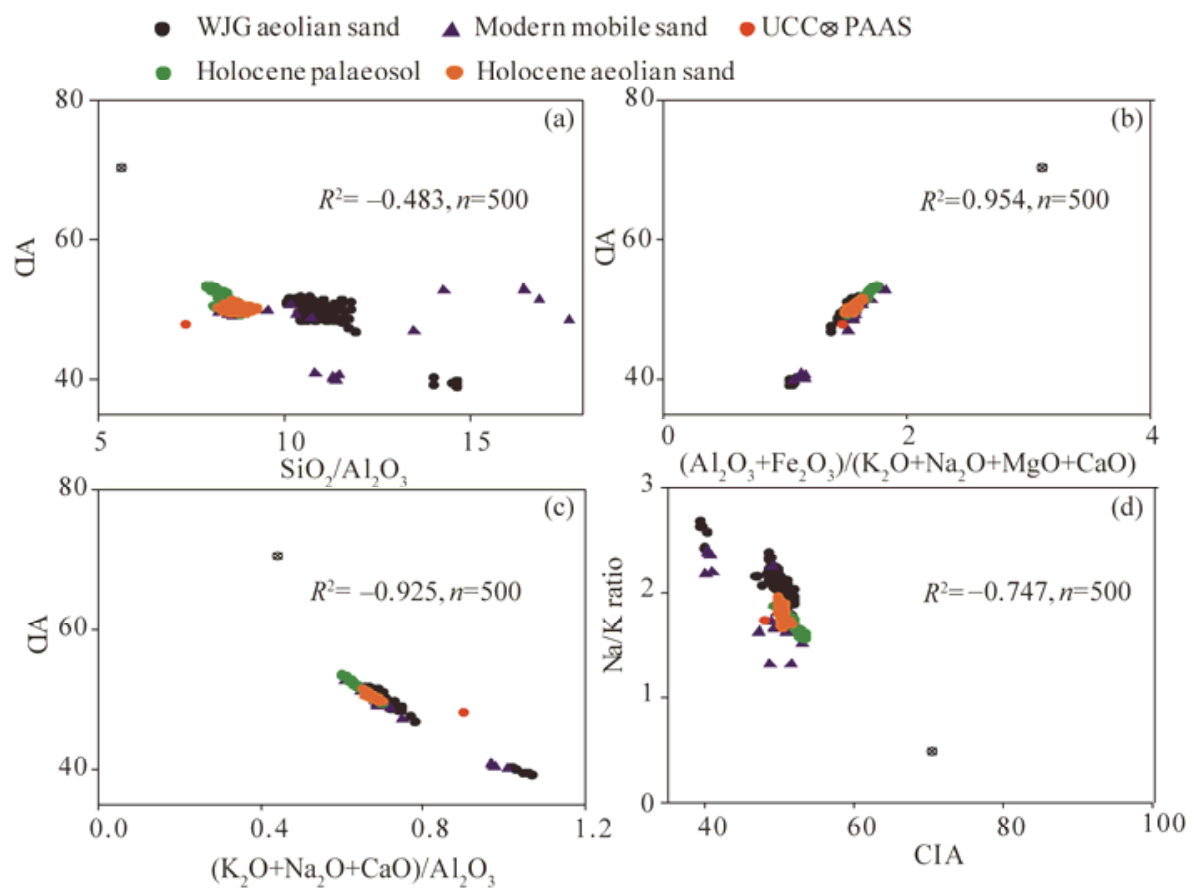

Fig. 4 Scatter diagrams of the different geochemical parameters in the Mu Us Desert. CIA, Chemical Index of Alteration.

Compared to the PAAS, there was similar leaching ratio $\left(\left(\mathrm{Al}_{2} \mathrm{O}_{3}+\mathrm{Fe}_{2} \mathrm{O}_{3}\right) /\left(\mathrm{K}_{2} \mathrm{O}+\mathrm{Na}_{2} \mathrm{O}+\mathrm{CaO}\right.\right.$ $+\mathrm{MgO})$ ) in different types of desert deposits in the $\mathrm{Mu}$ Us Desert (Table 3), which probably demonstrated the lower amplitude of variation in regional precipitation (moisture) during the Late Holocene and the Modern periods. In the WJG profile, the variations of leaching ratio (1.48-1.56; Table 3) in different layers of aeolian sand indicated similar moisture or precipitation conditions since the late Holocene. The scatter diagram of the leaching ratio and CIA indicated relatively concentrated distributions, which also evidenced this result (Fig. 4b). Moreover, we also found that the leaching degree was significantly positive with the CIA in the different types of desert deposits.

For the $\left(\mathrm{K}_{2} \mathrm{O}+\mathrm{Na}_{2} \mathrm{O}+\mathrm{CaO}\right) / \mathrm{Al}_{2} \mathrm{O}_{3}$, Table 3 indicates that it was $0.66-1.07$ and the average was 0.71 in the WJG profile, which was similar with that of the ratios in the different types of sandy deposits in the $\mathrm{Mu}$ Us Desert, e.g. surface deposits of the mobile sandy dunes, Holocene aeolian sand and palaeosol. Moreover, we found that the ratio remained relatively stable in the different aeolian sand layers of the WJG profile (Table 3). In Fig. 4c, scatter diagram indicated that the $\left(\mathrm{K}_{2} \mathrm{O}+\mathrm{Na}_{2} \mathrm{O}+\mathrm{CaO}\right) / \mathrm{Al}_{2} \mathrm{O}_{3}$ was negative with the geochemical weathering in the different types of desert deposits.

$\mathrm{Na} / \mathrm{K}$ ratio ranged from 1.04 to 1.58 in the WJG profile, with an average of 1.21 (Table 3). In the different layers of the aeolian sand in the WJG profile, the $\mathrm{Na} / \mathrm{K}$ ratio also presented very similar characteristics. However, the $\mathrm{Na} / \mathrm{K}$ ratios from the different layers of the WJG profile were relatively lower compared to the other deposits in this region. In order to explain this phenomenon, we drew the scatter diagram of the $\mathrm{Na} / \mathrm{K}$ and $\mathrm{CIA}$ from the aforementioned deposits (Fig. 4d). The results indicated that the partial scatters were overlapping, i.e. the surface deposits 
of the mobile sand dunes, aeolian sand of the WJG profile and Holocene aeolian deposits in the region. These results mirrored that the regional aeolian deposits probably had similar material sources and transported processes due to similar geochemical weathering characteristics.

The CIA is generally similar in the different types of desert deposits in the Mu Us Desert (Table 3). We therefore concluded that the aeolian deposits in the study area incurred weaker geochemical weathering or even unweathering under the cold-dry surrounding. Plotting the geochemical components as an $\mathrm{A}-\mathrm{CN}-\mathrm{K}$ ternary diagram (Fig. 5), we found that the geochemical components in different types of deposits in the Mu Us Desert were mainly distributed along the trend line of the chemical weathering from the UCC to PAAS, and were also similar to the weathering results of the UCC. This suggests that the sediments of the different types of deposits in the Mu Us Desert probably originated from the widespread UCC, they possessed highly consistent material sources, and they incurred very weak geochemical weathering. Secondly, the geochemical components of the deposits were all concentrated on the line of the Pi-Ks, and obviously far from the line of the Sm-Il, which also illustrated a generally similar weathering status of the different sand materials.

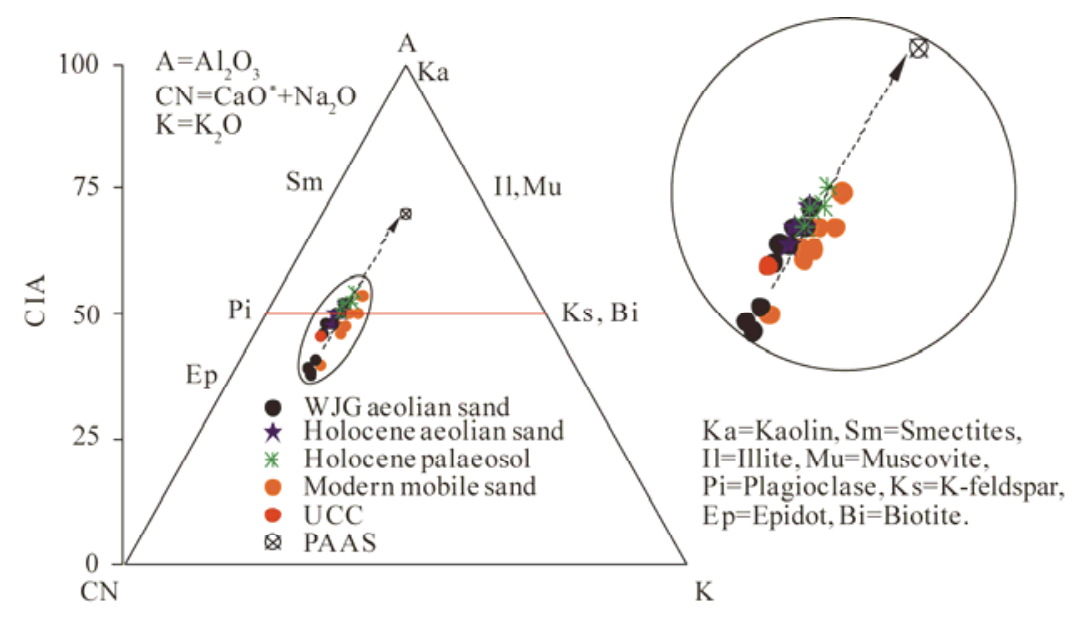

Fig. $5 \mathrm{~A}-\mathrm{CN}-\mathrm{K}$ triangle mode diagram of the different deposits in the Mu Us Desert

\section{Discussion}

\subsection{Geochemical parameters inferred the climatic variation from the WJG profile}

Geochemical behavior of the aeolian deposits was mainly controlled by temperature and precipitation conditions (Chen et al., 2008). In the Asian monsoonal boundary zone, regional temperature and precipitation are related to the change of the Asian summer monsoonal intensity (Liu et al., 2014b). Therefore, the geochemical study possibly provided the detailed climatic variations and their response to global environmental change.

Based on geochemical parameter variation and direct OSL ages from the WJG profile, several cold-dry and relatively warm-wet intervals were discovered during the past $4.2 \mathrm{ka} \mathrm{BP}$ (Figs. 6a-e). Layer $6, \mathrm{SiO}_{2} / \mathrm{Al}_{2} \mathrm{O}_{3}$ approached the maximum in the profile, implying a stronger winter monsoon. The CIA was clearly lower while the $\mathrm{Na} / \mathrm{K}$ ratio sharply increased. Rapidly declined $\left(\mathrm{Al}_{2} \mathrm{O}_{3}+\mathrm{Fe}_{2} \mathrm{O}_{3}\right) /\left(\mathrm{K}_{2} \mathrm{O}+\mathrm{Na}_{2} \mathrm{O}+\mathrm{CaO}+\mathrm{MgO}\right)$ and enhanced $\left(\mathrm{K}_{2} \mathrm{O}+\mathrm{Na}_{2} \mathrm{O}+\mathrm{CaO}\right) / \mathrm{Al}_{2} \mathrm{O}_{3}$ reflected a weaker leaching degree in the deposits. These proxies indicated that the regional climate was predominantly cold and dry around $4.2 \mathrm{ka} \mathrm{BP}$, resulting in the apparently weaker weathering and leaching degrees. Layer 5, the $\mathrm{SiO}_{2} / \mathrm{Al}_{2} \mathrm{O}_{3}$ and $\mathrm{Na} / \mathrm{K}$ ratio became very lower, whereas the CIA presented the prominent high value. The ratios of $\left(\mathrm{Al}_{2} \mathrm{O}_{3}+\mathrm{Fe}_{2} \mathrm{O}_{3}\right) /\left(\mathrm{K}_{2} \mathrm{O}+\mathrm{Na}_{2} \mathrm{O}+\mathrm{CaO}+\mathrm{MgO}\right)$ and $\left(\mathrm{K}_{2} \mathrm{O}+\mathrm{Na}_{2} \mathrm{O}+\mathrm{CaO}\right) / \mathrm{Al}_{2} \mathrm{O}_{3}$ showed an increased leaching degree for the deposits. That is, the climate was probably ameliorative in 4.2-3.0 ka BP. Layer 4, the detailed climate change can be divided into two sub-stages. In $225-248 \mathrm{~cm}$ soil layer, the geochemical parameters showed an 
opposite change, reflecting relatively cold and dry conditions. Combined with the OSL age $(3.0 \pm 0.2 \mathrm{ka} \mathrm{BP})$ in the profile, we proposed that this interval was possibly corresponding to the widespread $2.8 \mathrm{ka} \mathrm{BP}$ cold event. In the 200-225 cm soil layer, the ratios of $\mathrm{SiO}_{2} / \mathrm{Al}_{2} \mathrm{O}_{3}, \mathrm{Na} / \mathrm{K}$ and $\left(\mathrm{K}_{2} \mathrm{O}+\mathrm{Na}_{2} \mathrm{O}+\mathrm{CaO}\right) / \mathrm{Al}_{2} \mathrm{O}_{3}$ became remarkably lower, while the values of $\left(\mathrm{Al}_{2} \mathrm{O}_{3}+\mathrm{Fe}_{2} \mathrm{O}_{3}\right) /$ $\left(\mathrm{K}_{2} \mathrm{O}+\mathrm{Na}_{2} \mathrm{O}+\mathrm{CaO}+\mathrm{MgO}\right)$ and $\mathrm{CIA}$ apparently increased, indicating a transiently warm and humid climate. Layer 3, the relative high ratios of $\mathrm{SiO}_{2} / \mathrm{Al}_{2} \mathrm{O}_{3}, \mathrm{Na} / \mathrm{K}$ and $\left(\mathrm{K}_{2} \mathrm{O}+\mathrm{Na}_{2} \mathrm{O}+\mathrm{CaO}\right) / \mathrm{Al}_{2} \mathrm{O}_{3}$ were coincident with the rapidly declined $\mathrm{CIA}$ and $\left(\mathrm{Al}_{2} \mathrm{O}_{3}+\mathrm{Fe}_{2} \mathrm{O}_{3}\right) /\left(\mathrm{K}_{2} \mathrm{O}+\mathrm{Na}_{2} \mathrm{O}+\mathrm{CaO}+\mathrm{MgO}\right)$, although they had frequent fluctuations. In general, the region was dominated by a cold and dry climate around 2.1-1.8 ka BP. Layer 2, the declined $\mathrm{SiO}_{2} / \mathrm{Al}_{2} \mathrm{O}_{3}$ indicated a rapidly decreased winter monsoonal strength, whereas the weathering and leach degrees tended to increase around 1.8-0.9 ka BP. Figure 6 (yellow rectangle) indicated that enhanced weathering and leaching conditions and the weakest Asian winter monsoon emerged around $0.9 \mathrm{ka} \mathrm{BP}$, which is consistent with the Medieval warm period (MWP) in northern China. Layer 1, the geochemical parameters from the WJG profile indicated that the climate became cold and dry since $0.9 \mathrm{ka} \mathrm{BP}$, as revealed by the increased $\mathrm{SiO}_{2} / \mathrm{Al}_{2} \mathrm{O}_{3}$ and declined CIA, which corresponds to the Little Ice Age (LIA) after the MWP.

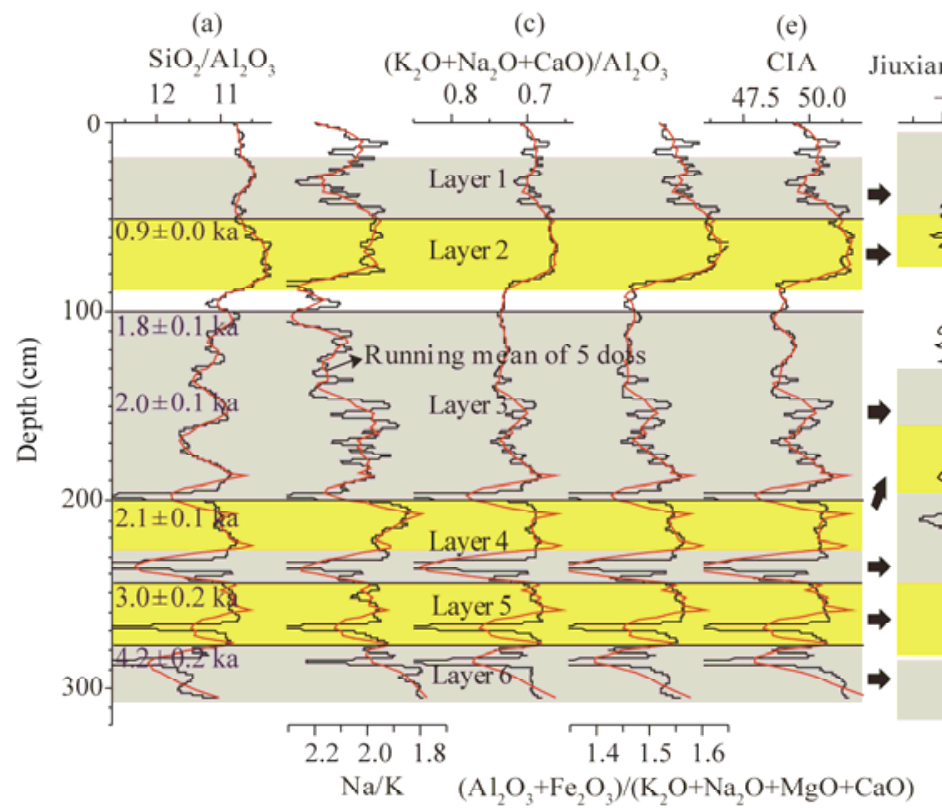

(b)

(d) (f) (h)

$\operatorname{IRD}(\%)$

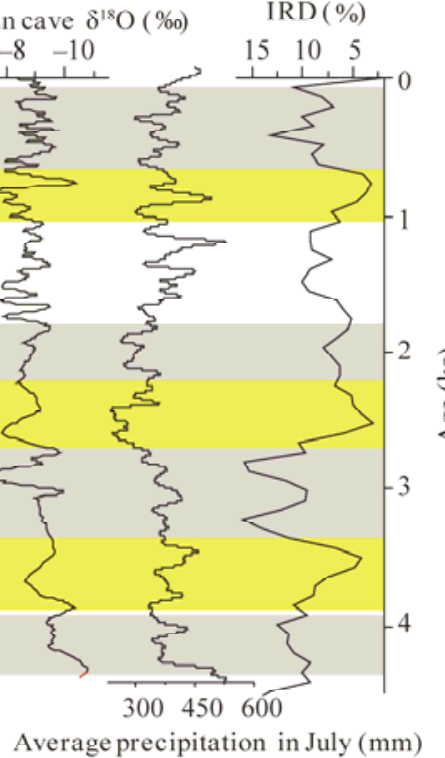

(g)

Fig. 6 Comparison of the climatic variation in the Mu Us Desert and the different archives in the Northern Hemisphere. a-e, geochemical indicators in the WJG profile; f, stalagmite record in Jiuxian cave (Cai et al., 2010); g, precipitation in the Daihai Lake (Xu et al., 2010); h, ice rafting debris (IRD) events in the North Atlantic Ocean (Bond et al., 1997).

\subsection{Comparison of the climatic variation across the monsoonal boundary zone and its link with the low and high latitudes of the Northern Hemisphere}

In the southeastern $\mathrm{Mu}$ Us Desert, geochemical study of the WJG profile indicated that several cold-dry and relatively warm-wet cycles occurred during the past $4.2 \mathrm{ka} \mathrm{BP}$, such as, the cold events around 4.2, 2.8 ka BP and LIA and relatively warm intervals of 4.2-3.0 ka BP and MWP. Similar climatic records are also documented in other archives across the monsoonal boundary zone of northern china (Figs. $6 \mathrm{f}-\mathrm{h}$ ). For example, pollen analysis indicates that the average temperature and rainfall in July were lower by $2.2^{\circ} \mathrm{C}$ and $14 \mathrm{~mm}$ around Daihai Lake during 4.45-4.22 ka BP, compared to the Modern period (Xu et al., 2010; Fig. 6g). The increased $\delta^{18} \mathrm{O}$ from the Jiuxian cave demonstrated an abrupt weakening in the Asian summer monsoonal strength and an decrease in monsoonal precipitation (Cai et al., 2010; Fig. 6f). Additionally, this 
cold interval was also recorded by deep sea deposits in the North Atlantic (Bond et al., 1997; Fig. $6 \mathrm{~h}$ ). Subsequently, temperature and precipitation were higher by $2.8^{\circ} \mathrm{C}$ and $30 \mathrm{~mm}$ than the Modern Epoch in Daihai Lake during 3.9-3.5 ka BP (Fig. 6g). The momentarily increased Asian summer precipitation was coincident with the decreased amount of floating ice in the low and high latitudes of the Northern Hemisphere (Figs. 6f and h).

For the cold interval around $2.8 \mathrm{ka} \mathrm{BP}$ in the southeastern Mu Us Desert, Chen et al. (2006) found declined pollen concentrations in the Sanjiaocheng profile, which indicated that the lake had completely dried up during that period. Similarly, the average temperature and precipitation in July were lower by about $2.5^{\circ} \mathrm{C}$ and $100 \mathrm{~mm}$ around this phase, marking a drastically cold and dry environment (Xu et al., 2010; Fig. 6g). Analysis of cave and peat deposits indicates that a millennial-scale weaker summer monsoonal signal took place (Wang et al., 2005; Cai et al., 2010; Liu et al., 2014b). This was possibly related to the cold event at high latitudes in the Northern Hemisphere through the thermohaline circulation (THC) between the southern and northern oceans (Hong et al., 2003) and the westerlies between the North Atlantic region and the Eurasia mainland (Wang et al., 2005).

In the MWP of northern China, the monsoonal boundaries of deserts such as the Horqin, Otindag and $\mathrm{Mu}$ Us, the landscape was dominated by steppe and grass savanna (Wu et al., 2004). Around $0.9-1.2 \mathrm{ka} \mathrm{BP}$, the chemical weathering was the strongest during the last 2,000 years in Daihai Lake, accompanied with gradually enhanced lake biological productivity and a greatly raised lake level (Jin et al., 2002). This relatively warm and humid interval was also recorded by lake deposits, tree rings and historical documents (Liu et al., 2011; Chen et al., 2015).

The climate became very cold and dry in the Mu Us Desert since $0.9 \mathrm{ka}$ BP. Similar, sandy deposits were stronger accumulated in the Otindag Sandy Land, with clearly declined magnetic susceptibility, organic matter in the deposits in 0.7-0.2 ka BP (Jin et al., 2004a). The Juyanhai Lake became shallow around the cold interval in AD 1370-1920 (Jin et al., 2004b). Afterwards, a relatively warm regional climate, which corresponds to the sod horizon in the top of the WJG profile, was probably related to the modern warm period since the start of the $20^{\text {th }}$ century.

\section{Conclusions}

We systematically conducted geochemical analyses from the modern mobile sand, and paleo-aeolian sand of the WJG profile in the Mu Us Desert, northern China, and reconstructed the past climatic condition based on geochemical characteristics and their environmental significance. Several preliminary conclusions are as follows: (1) the geochemical components of the aeolian deposits in that region were dominated by $\mathrm{SiO}_{2}, \mathrm{Al}_{2} \mathrm{O}_{3}$ and $\mathrm{Na}_{2} \mathrm{O}$. The deposits probably originated from the widespread UCC and underwent long-term weathering, transport and re-deposition; (2) in general, the geochemical parameters reflected the relatively stable environmental conditions during the Late Holocene and the Modern Epoch. The deposits were subjected to weak weathering and even lack of weathering under the cold and dry climate conditions, and the different types of desert deposits had highly similar material sources and weathering and leaching degrees; and (3) the direct OSL dating ages and geochemical parameters from the WJG profile demonstrated that regional climate changes included several typically cold and warm events, e.g. 4.2, $2.8 \mathrm{ka}$ BP, Little Ice Age and Medieval Warm Period. Our comparative study also demonstrated that these events were coincident with the Asian summer monsoonal strength change and the periodic cold events in the high latitudes of the Northern Hemisphere.

\section{Acknowledgements}

This research was funded by the Knowledge Innovation Program of the Chinese Academy of Sciences (KZZD-EW-04-04), the National Natural Science Foundation of China (41271215, 41501220), the China Postdoctoral Science Foundation (2015M570861), the Excellent Youth Scholars of Cold and Arid Regions Environmental and Engineering Research Institute, Chinese Academy of Sciences (51Y451211) and the State Key Laboratory of Earth Surface Processes and Resource Ecology, Beijing Normal University (2015-KF-13). We 
kindly thank Prof. ZHAO Hua from the Institute of Hydrogeology and Environmental Geology, Chinese Academy of Geological Sciences for the determination of the OSL ages. We thank the anonymous reviewers and editors for their helpful comments.

\section{References}

Bond G, Showers W, Cheseby M, et al. 1997. A pervasive millennial-scale cycle in North Atlantic Holocene and glacial climates. Science, 278(5341): 1257-1266.

Cai Y J, Tan L C, Cheng H, et al. 2010. The variation of summer monsoon precipitation in central China since the last deglaciation. Earth and Planetary Science Letters, 291(1-4): 21-31.

Chen F H, Cheng B, Zhao Y, et al. 2006. Holocene environmental change inferred from a high-resolution pollen record, Lake Zhuyeze, arid China. The Holocene, 16(5): 675-684.

Chen J, Ji J F, Qiu G, et al. 1998. Geochemical studies on the intensity of chemical weathering in Luochuan loess-paleosol sequence, China. Science in China Series D: Earth Sciences, 41(3): 235-241.

Chen J, An Z S, Liu L W, et al. 2001. Variations in chemical compositions of the eolian dust in Chinese Loess Plateau over the past 2.5 Ma and chemical weathering in the Asian inland. Science in China Series D: Earth Sciences, 44(5): 403-413.

Chen J H, Chen F H, Feng S, et al. 2015. Hydroclimatic changes in China and surroundings during the Medieval Climate Anomaly and Little Ice Age: spatial patterns and possible mechanisms. Quaternary Science Reviews, 107: 98-111.

Chen Y Y, Li X S, Han Z Y, et al. 2008. Chemical weathering intensity and element migration features of the Xiashu loess profile in Zhenjiang, Jiangsu Province. Journal of Geographical Sciences, 18(3): 341-352.

Fedo C M, Nesbitt H W, Young G M. 1995. Unraveling the effects of potassium metasomatism in sedimentary rocks and paleosols, with implications for paleoweathering conditions and provenance. Geology, 23(10): 921-924.

Guo Z T, Ruddiman W F, Hao Q Z, et al. 2002. Onset of Asian desertification by 22 Myr ago inferred from loess deposits in China. Nature, 416(6877): 159-163.

Hong Y T, Hong B, Lin Q H, et al. 2003. Correlation between Indian Ocean summer monsoon and north Atlantic climate during the Holocene. Earth and Planetary Science Letters, 211(3-4): 371-380.

Jia F F, Lu R J, Gao S Y, et al. 2015. Holocene aeolian activities in the southeastern Mu Us Desert, China. Aeolian Research, 19: $267-274$

Jin H L, Su Z Z, Sun Z. 2003. Characters of chemical elements in strata of middle and late Holocene in Hunshandake Desert and the indicating climatic changes. Journal of Desert Research, 23(4): 366-371 (in Chinese).

Jin H L, Su Z Z, Sun L Y, et al. 2004a. Holocene climatic change in Hunshandake Desert. Chinese Science Bulletin, 49(16): $1730-1735$.

Jin H L, Xiao H L, Sun L Y, et al. 2004b. Vicissitude of Sogo Nur and environmental-climatic change during last 1500 years. Science in China Series D: Earth Sciences, 47(Supp1.1): 61-70.

Jin Z D, Shen J, Wang S M, et al. 2002. The medieval warm period in the Daihai Area. Journal of Lake Sciences, 14(3): 209-216. (in Chinese)

Li B S, Wen X H, David Z, et al. 2008. Paleoclimate change recorded in the red earth and brown-yellow sediment of Late Quaternary for northeastern part of Guangdong Province, south to the Nanling Mountains, China. Chinese Science Bulletin, 53(24): 3866-3875.

Li X S, Yang D Y, Lu H Y. 1999. Oxide-geochemistry features and paleoclimatic record of the aeolian-dust depositional sequence in southern Anhui Province. Marine Geology \& Quaternary Geology, 19(4): 75-82. (in Chinese)

Liang M Y, Guo Z T, Kahmann A J, et al. 2009. Geochemical characteristics of the Miocene eolian deposits in China: Their provenance and climate implications. Geochemistry, Geophysics, Geosystems, 10(4), doi: 10.1029/2008GC002331.

Liu B, Jin H L, Sun L Y, et al. 2014a. Holocene moisture change revealed by the $\mathrm{Rb} / \mathrm{Sr}$ ratio of aeolian deposits in the southeastern Mu Us Desert, China. Aeolian Research, 13: 109-119.

Liu B, Jin H L, Sun Z, et al. 2014b. Evidence of Holocene millennial-scale climatic change from Gonghe Basin peat deposit, northeastern Qinghai-Tibet Plateau. Journal of Arid Environments, 106: 1-10.

Liu B, Jin H L, Sun L Y, et al. 2015. Geochemical evidence for Holocene millennial-scale climatic and environmental changes in the south-eastern Mu Us Desert, northern China. International Journal of Earth Sciences, 104(7): 1889-1900.

Liu J B, Chen F H, Chen J H, et al. 2011. Humid Medieval Warm Period recorded by magnetic characteristics of sediments from Gonghai Lake, Shanxi, North China. Chinese Science Bulletin, 56(23): 2464-2474.

Lu H Y, Miao X D, Zhou Y L, et al. 2005. Late Quaternary aeolian activity in the Mu Us and Otindag dune fields (north China) and lagged response to insolation forcing. Geophysical Research Letters, 32(21), doi: 10.1029/2005GL024560. 
Ma J, Yue L P, Yang L R, et al. 2011. OSL dating of Holocene sequence and palaeoclimate change record in southeastearn margin of Mu Us desert, north China. Quaternary Sciences, 31(1): 120-129. (in Chinese)

McLennan S M. 1993. Weathering and global denudation. The Journal of Geology, 101(2): 295-303.

Nesbitt H W, Young G M. 1982. Early Proterozoic climates and plate motions inferred from major element chemistry of lutites. Nature, 299(5885): 715-717.

Peng S Z, Guo Z T. 2001. Geochemical indicator of original eolian grain size and implications on winter monsoon evolution. Science in China Series D: Earth Sciences, 44(Supp1.1): 261-266.

Qiao Y S, Zhao Z Z, Wang Y, et al. 2009. Variations of geochemical compositions and the paleoclimatic significance of a loess-soil sequence from Garzê County of western Sichuan Province, China. Chinese Science Bulletin, 54(24): 4697-4703.

Sun J M, Li S H, Han P, et al. 2006. Holocene environment changes in the central Inner Mongolia, based on the single-aliquot-quartz optical dating and multi-proxy study of dune sands. Palaeogeography, Palaeoclimatology, Palaeoecology, 233(1-2): 51-62.

Taylor S R, McLennan S M. 1985. The Continental Crust: Its Composition and Evolution. Oxford, UK: Blackwell Scientific Publications.

Wang Y J, Cheng H, Edwards R L, et al. 2005. The Holocene Asian monsoon: links to solar changes and north Atlantic climate. Science, 308(5723): 854-857.

Wu J W, Lu R J, Zhao T N. 2004. Sandy lands during the medieval warm period in Eastern China. Science of Soil and Water Conservation, 2(1): 29-33. (in Chinese)

Xie Y Y, Meng J, Guo L F, et al. 2013. Geochemical composition and weathering feature of surface sediment in the Dumen Sandy land, northeast China. Journal of Desert Research, 33(4): 1009-1018. (in Chinese)

Xu Q H, Xiao J L, Li Y C, et al. 2010. Pollen-based quantitative reconstruction of Holocene climate changes in the Daihai Lake Area, Inner Mongolia, China. Journal of Climate, 23(11): 2856-2868.

Xu Z W, Lu H Y, Zhao C F, et al. 2011. Composition, origin and weathering process of surface sediment in Kumtagh Desert, Northwest China. Journal of Geographical Sciences, 21(6): 1062-1076.

Yao Z Q, Xiao G Q, Liang M Y. 2010. Global cooling controls on the chemical weathering as evidenced from the Plio-Pleistocene deposits of the North China Plain. Chinese Science Bulletin, 55(9): 787-790. 